\title{
Analisis Pengelolaan Dana Bantuan Operasional Sekolah (BOS) pada Satuan Pendidikan Dasar di Kota Kotamobagu
}

\section{JULIANTI PONTOH ${ }^{1}$, VENTJE ILAT ${ }^{2}$, HENDRIK MANOSSOH ${ }^{3}$}

\author{
${ }^{123}$ Program Magister Akuntansi, Fakultas Ekonomi dan Bisnis Universitas Sam Ratulangi \\ email: juliantipontoh@gmail.com ${ }^{1}$, ventje_ilat@ unsrat.ac.id ${ }^{2}$, hendrikmanossoh@yahoo.com ${ }^{3}$
}

\begin{abstract}
Indonesian Government has increased the quality of their education. One of their efforts is by providing School Operational Funding. However, there is a lack of supervision in managing the funding. BPK, BPKP, Inspectorate of North Sulawesi Province and the city of Kotamobagu had not yet conducted any audit on the fundings from 2012 to 2016. BPK has only monitored or controlled the funding whether they are genuinely transferred from central government to School Education Unit and to each school in City of Kotamobagu. From the supervising point of view, nor has School Committee implemented their supervising functions sufficiently. Therefore, this research is intended to investigate such phenomena. This is a qualitative exploratory research. Data were collected by in-depth interviews and document analysis. Data were validated by triangulations: researchers, theory and sources of data. Findings indicate that there are some constraints in managing BOS: supervision, human resources, communication and bureaucracy structure. Those four factors are crucial in relation to manage the funding complying with regulations.
\end{abstract}

Keywords: School Operational Funding Management, Supervision, Human Resources, Communication and Bureaucracy Structure

Abstrak. Pemerintah Republik Indonesia berusaha meningkatan pelayanan dan kualitas pendidikan dengan memberikan Bantuan Operasional Sekolah (BOS). Akan tetapi, kurangnya pengawasan dalam pengelolaan dana BOS di Kota Kotamobagu sangatnya tadi lapangan. BPK, BPKP, Inspektorat Propinsi Sulawesi Utara maupun Inspektorat Daerah Kota Kotamobagu belum melakukan audit terhadap pengelolaan dana BOS di Kota Kotamobagu dari tahun 2012 sampai tahun 2016. Selama ini BPK tidak melakukan audit tapi hanya sekedar mengontrol atau memonitoring apakah dana BOS yang disalurkan dari pusat telah diterima oleh Satuan Pendidikan Dasar di Kota Kotamobagu sesuai dengan dana yang ditransferkan ke rekening masing-masing sekolah. Dari segi pengawasan masyarakat, komite sekolah yang seharusnya menjalankan fungsi ini juga tidak melakukannya dengan baik. Oleh sebab itu, penelitian ini bertujuan untuk menganalisis fenomena yang terjadi.Penelitian ini menggunakan metode penelitian kualitatif dengan pendekatan eksploratori (exploratory approach). Data diperoleh melalui wawancara mendalam (indepth interviews), dan dokumentasi (documentation). Sedangkan validitas data yang digunakan adalah triangulasi peneliti, triangulasi teori, dan triangulasi sumber data. Hasil analisis dan pembahasan menyimpulkan bahwa terjadi beberapa hambatan dalam pengelolaan dana BOS. Hambatan-hambatan tersebut adalah masalah-masalah yang terjadi karena pengawasan, sumber daya, komunikasi dan struktur birokrasi. Keempat hal tersebut sangat penting dalam hubungannya dengan pengelolaan dana BOS agar pelaksanannya sesuai dengan regulasi yang ada.

Kata Kunci: Pengelolaan Dana BOS, Pengawasan, Sumber Daya, Komunikasi dan Struktur Birokrasi

\section{Pendahuluan}

Sejak diberlakukannya otonomi daerah di Indonesia, pemerintah daerah merupakan organisasi sektor publik yang diberi kewenangan oleh pemerintah pusat untuk mengatur pemerintahannya sendiri. Kewenangan pemerintah daerah dalam pelaksanaan otonomi daerah diatur dalam Undang-Undang Nomor 32 Tahun 2004 tentang Pemerintahan Daerah, yang diubah dengan Undang-Undang Nomor 23 Tahun 2014, pasal 1 ayat 6 "Otonomi daerah adalah hak, wewenang dan kewajiban daerah otonom untuk mengatur dan mengurus sendiri urusan pemerintahan dan kepentingan masyarakat setempat dalam sistem Negara Kesatuan Republik Indonesia."

Penerapan otonomi daerah di Indonesia, memilih cara desentralisasi dalam pemerintahannya. Desentralisasi adalah pengalihan tanggungjawab, kewenangan dan sumber-sumber daya dari pusat ke daerah, dimaksudkan agar daerah dapat langsung merasakan program dan pelayanan yang dirancang dan dilaksanakan oleh pusat di daerah masing-masing (Sujarweni, 2015:233).Wujud dari desentralisasi, Indonesia adalah negara berkembang yang mempunyai tingkat perhatian yang tinggi terhadap pendidikan anak bangsa. Dalam Undang-Undang Republik Indonesia Nomor 20 Tahun 2003 tentang Sistem Pendidikan Nasional, pasal 5 ayat 1 setiap warga Negara mempunyai hak yang sama untuk memperoleh pendidikan yang bermutu dan pasal 6 ayat 1-2 mengatakan bahwa (1) Setiap warga negara yang berusia tujuh sampai dengan lima belas (15) tahun wajib mengikuti pendidikan dasar; dan (2) Setiap warga negara bertanggungjawab terhadap keberlangsungan penyelenggaraan pendidikan. 
Kebijakan Pemerintah dengan dicanangkannya program wajib belajar Pendidikan Dasar 9 (Sembilan) tahun merupakan upaya lanjutan dalam memenuhi amanat Undang-Undang Dasar 1945 pasal 31 ayat 1, yang menyatakan bahwa setiap warga negara berhak atas pendidikan dan dalam Undang-Undang Nomor 20 Tahun 2003, pasal 34 ayat 2 bahwa Pemerintah dan Pemerintah Daerah menjamin terselenggaranya wajib belajar minimal pada jenjang pendidikan dasar tanpa memungut biaya.

Salah satu indikator penuntasan program wajib belajar sembilan (9) tahun dapat diukur dengan Angka Partisipasi Kasar (APK) SD dan SMP. Pada tahun 2005 APK SD telah mencapai 115\%, sedangkan SMP pada tahun 2009 telah mencapai 98,11\%, sehingga program wajar 9 tahun telah tuntas 7 tahun lebih awal dari target deklarasi Education For All (EFA) di Dakar. Program Bantuan Operasional Sekolah (BOS) yang dimulai sejak bulan Juli 2005, telah berperan secara signifikan dalam percepatan pencapaian program wajar 9 tahun. Oleh karena itu, mulai tahun 2009 pemerintah telah melakukan perubahan tujuan, pendekatan dan orientasi program BOS, dari perluasan akses menuju peningkatan kualitas.

Program BOS adalah program pemerintah yang pada dasarnya untuk penyediaan pendanaan biaya operasional nonpersonalia bagi satuan pendidikan dasar sebagai pelaksana program wajib belajar. Dasar pelaksanaan dana BOS adalah (1) Peraturan Menteri Dalam Negeri nomor 62 tahun 2011 tentang pedoman pengelolaan dana BOS, (2) Peraturan Menteri Pendidikan dan Kebudayaan Nomor 16 tahun 2016 tentang petunjuk teknis penggunanan dan pertanggungjawaban keuangan dana BOS untuk Sekolah Dasar dan Menengah Pertama, (3) Peraturan Menteri Keuangan tentang pedoman umum dan alokasi dana BOS.

Peraturan Menteri Pendidikan dan Kebudayaan Republik Indonesia nomor 16 tahun 2016 menyebutkan tujuan dana BOS SD dan SMP secara umum untuk meringankan beban masyarakat terhadap pembiayaan pendidikan dalam rangka wajib belajar 9 tahun yang bermutu serta berperan dalam mempercepat pencapaian Standar Pelayanan Minimal (SPM) pada sekolah yang belum memenuhi SPM, dan pencapaian Standar Nasional Pendidikan (SNP) pada sekolah yang sudah memenuhi SNP dan secara khusus program BOS SD dan SMP bertujuan untuk (1) membebaskan pungutan bagi seluruh siswa SD/SDLB negeri dan SMP/SMPLB/SMPT (Terbuka) negeri terhadap biaya operasional sekolah; (2) membebaskan pungutan seluruh siswa miskin dari seluruh pungutan di sekolah negeri dan swasta; (3) meringankan beban biaya operasi sekolah bagi siswa di sekolah swasta.

Peranan program BOS bukan hanya untuk mempertahankan jumlah peserta didik, tetapi berkontribusi dalam meningkatkan mutu pendidikan dasar. Selain itu, kenaikan jumlah dana BOS yang signifikan mulai tahun 2009 diharapkan akan menjadikan BOS sebagai pilar utama mewujudkan pendidikan dasar tanpa dipungut biaya dan konsekuensinya pemerintah wajib memberikan layanan pendidikan bagi seluruh peserta didik pendididkan dasar. Mekanisme penyaluran dana BOS dari tahun ke tahun mengalami perubahan mulai dari tahun 2005-2010 penyaluran dana BOS dari kas umum Negara (RKUN) langsung transfer ke rekening sekolah; tahun 2011 mekanisme penyalurannya berubah dari kas umum Negara (RKUN) transfer ke kas umum daerah (RKUD) pemerintah kabupaten/kota baru ke rekening sekolah; dan tahun 2012 sampai sekarang mekanisme penyalurannya dari kas umum Negara (RKUN) transfer ke kas umum daerah (RKUD) pemerintah propinsi baru transfer ke rekening sekolah.

Data Pokok Pendidikan (Dapodik) adalah sistem basis online dan terintegrasi nasional yang menyangkut data pokok pendidikan, meliputi sekolah termasuk sarana dan prasarana, pendidik dan tenaga kependidikan (PTK), peserta didik (siswa), dan proses pembelajaran di dalam rombongan belajar (rombel); data tersebut digunakan sebagai acuan data dalam program pendidikan pemerintah; data dapodik yang digunakan dalam pengalokasian dana BOS yaitu data jumlah siswa tiap sekolah (DJPK, 2017).

Berdasarkan Juknis tahun 2016, penggunaan dana BOS hanya dapat digunakan untuk membiayai 13 komponen belanja/kegiatan yaitu (1) Pengembangan perpustakaan; (2) Kegiatan penerimaan peserta didik baru; (3) Kegiatan pembelanjaan dan ekstrakurikuler; (4) Kegiatan ulangan dan ujian; (5) Pembelian bahan habis pakai; (6) Langganan daya dan jasa; (7) Perawatan sekolah/rehab ringan dan sanitasi sekolah;(8) Pembayaran honorarium bulanan; (9) Pengembangan profesi guru dan tenaga kependidikan;(10) Membantu peserta didik miskin;(11) Pembiayaan pengelolaan sekolah;(12) Pembelian dan perawatan perangkat komputer; dan (13) Biaya lainnya, jika seluruh komponen 1 sampai dengan 12 telah terpenuhi pendanaannya dari BOS. Sedangkan untuk Juknis tahun 2017, penggunaan dana BOS hanya dapat digunakan untuk membiayai 11 komponen belanja/kegiatan.

Besaran dana BOS yang diterima tiap sekolah dihitung berdasarkan jumlah siswa per sekolah dan waktu penyaluran dana BOS ini diberikan ke sekolah per triwulan untuk daerah tidak terpencil, sedangkan untuk 
daerah terpencil penyaluran dana BOS diberikan ke sekolah per-semester dengan alokasi dana seperti pada tabel 1 berikut ini:

\section{Tabel 1}

Penyaluran Dana BOS

Propinsi/Kabupaten/Kota

Tahun 2016/2017

\begin{tabular}{|l|l|l|}
\hline Alokasi Sekolah & $\begin{array}{l}\text { Besar satuan biaya } \\
\text { dana BOS }(\mathbf{R p})\end{array}$ & $\begin{array}{l}\text { Perhitungannya } \\
\text { (jumlah siswa } \geq \mathbf{6 0} \text { siswa) }\end{array}$ \\
\hline SD/SDLB & $800.000 /$ siswa/tahun & $\begin{array}{l}\text { Dihitung dari jumlah siswa dikalikan } \\
\text { dengan besar satuan biaya }\end{array}$ \\
\hline SMP/SMPLB/SMPT & $1.000 .000 /$ siswa/tahun & $\begin{array}{l}\text { Dihitung dari jumlah siswa dikalikan } \\
\text { dengan besar satuan biaya }\end{array}$ \\
\hline SLB & $\begin{array}{l}800.000 / \text { siswa/tahun }+ \\
1.000 .000 / \text { siswa/tahun }\end{array}$ & $\begin{array}{l}\text { Dihitung dari jumlah siswa SD dikalikan } \\
\text { dengan besar satuan biaya, ditambahkan } \\
\text { dengan jumlah siswa SMP dikalikan } \\
\text { dengan besar satuan biaya. }\end{array}$ \\
\hline
\end{tabular}

Sumber data: Juknis Dana BOS 2016/2017(data diolah)

Pengelolaan dana BOS yang berpedoman pada Peraturan Menteri Dalam Negeri Nomor 62 tahun 2011 tentang pedoman pengelolaan dana BOS, yang didalamnya mengatur (1) mekanisme penganggaran dana BOS, (2) pelaksanaan dan penatausahaan dana BOS, serta (3) pertanggungjawaban dana BOS. Sasaran penerima dana BOS berdasarkan petunjuk teknis (juknis) tahun 2016 adalah semua sekolah SD/SDLB,SMP/SMPLB/SMPT/Satap/SLB, baik negeri maupun swasta yang sudah terdata dalam sistem data pokok pendidikan dasar dan menengah (Dapodikdasmen). Khusus bagi sekolah swasta, harus memiliki izin operasional.

Pemerintah Kota Kotamobagu (Pemkot) melalui Dinas Pendidikan Daerah Kota Kotamobagu, menegaskan untuk penyaluran BOS bagi siswa-siswi yang berhak menerima, itu harus disalurkan dengan tepat pada sasaran (deliknews, 23/02/2016). Satuan pendidikan dasar di Kota Kotamobagu terdiri dari 70 Sekolah Dasar (SD/SDLB) dan 14 Sekolah Menengah Pertama (SMP/SMPLB) selang tahun 2016 dengan penyaluran dana BOS untuk satuan pendidikan dasar sebesar Rp 16.076.900.000,- dimana Dinas Pendidikan Daerah Propinsi Sulawesi Utara telah menyalurkan dana BOS tersebut lewat rekening masing-masing sekolah.

Permasalahan dalam pengelolaan dana BOS di Kota Kotamobagu, dimana sekolah yang tidak dapat menyalurkan dana BOS sesuai dengan petunjuk teknis yang ada, dalam hal ini penggunaan dana tidak sesuai dengan peruntukkannya, pengawasan tidak efektif, tidak ada komite sekolah, dan dana BOS di pegang oleh kepala sekolah. Sedangkan pelaksanaan penyaluran dana BOS terhambat, apabila pengelolaan dana BOS di setiap sekolah belum membuat laporan realisasi dana BOS yang sudah digunakan pada triwulan sebelumnya dan pelaporan dana BOS yang digunakan tidak sesuai dengan petunjuk teknis yang berlaku dan belum dilaporkan, maka untuk pencairan dana BOS triwulan berikutnya tidak akan dicairkan.

Dalam pengelolaan dana BOS, pengawasan sangat diperlukan sesuai dengan Peraturan Menteri Pendidikan Dan Kebudayaan Nomor 16 Tahun 2016 tentang perubahan atas peraturan menteri pendidikan dan kebudayaan nomor 80 tahun 2015 tentang petunjuk teknis penggunaan dan pertanggungjawaban keuangan dana BOS. Dimana, pada bab.VIII menjelaskan mengenai pengawasan, pemeriksaan dan sanksi.

Dari sisi pengwasan sangat jelas, dimana kurangnya pengawasan dalam pengelolaan dana BOS baik BPK, BPKP, Inspektorat Propinsi Sulawesi Utara maupun Inspektorat Daerah Kota Kotamobagu belum melakukan audit terhadap pengelolaan dana BOS di Kota Kotamobagu dari tahun 2012 sampai tahun 2016. BPKP dan Inspektorat Daerah Kota Kotamobagu, terakhir melakukan audit pengelolaan dana BOS tahun 2011 hingga sekarang belum pernah melakukan audit lagi sehubungan dengan dana BOS. Sedangkan untuk BPK, tidak melakukan audit tapi hanya sekedar mengontrol atau memonitoring apakah dana BOS yang disalurkan dari pusat telah diterima oleh satuan pendidikan dasar di Kota Kotamobagu sesuai dengan dana yang ditransferkan ke rekening masing-masing sekolah. Dan dari pengawasan masyarakat, dalam hal ini komite sekolah juga tidak 
terlaksana/tidak aktif lagi di sekolah yang menjadi fokus penelitian. Selain dari pengawasan, pengelolaan dana BOS di Kota Kotamobagu juga bermasalah dari (1) pengadaan buku cetak (K-13), dimana dalam 1 (satu) tahun anggaran hanya dapat diambil pada triwulan II (dua) sebesar $20 \%$ dari anggaran yang ada di triwulan II (dua) tapi SMP Negeri 1 Kotamobagu merealisasikan belanja tersebut di triwulan III (tiga) pada hal dananya sudah ada di triwulan II (dua); (2) pengadaan printer, dimana dalam 1 (satu) tahun anggaran hanya diperbolehkan membeli printer sebanyak 1 unit tapi SMP Negeri 1 Kotamobagu dalam 1 (satu) tahun sudah membeli 2 unit printer; dan (3) Dana Bos di pegang oleh kepala sekolah, dalam arti kepala sekolah yang memegang dana BOS bukan bendahara BOS selaku pengelola dana BOS di sekolah.

\section{KerangkaPemikiran}

Menurut Ibrahim (2015:45) adalah gambaran atau bangun utuh suatu penelitian, dan merupakan perpaduan dari berbagi aspek, mulai dari permasalahan, aspek-aspek terkait yang hendak diteliti, hingga kemungkinankemungkinan dari keseluruhan proses penelitian. Dengan kata lain, kerangka konsep atau konseptual penelitian adalah gambaran atau bangunan menyeluruh dan utuh mengenai penelitian yang akan dilakukan, yang terdiri dari perpaduan unsur dan aspek yang saling terkait, yang menjadi acuan dan kerangka kerja penelitian. Artinya dengan kerangka konseptual, peneliti berusaha untuk membangun alur kerja dan logika berpikir yang rasional dan argumentative, komprehensif dan menyeluruh mengenai penelitian yang sedang dilakukan, sehingga menghasilkan kesimpulan yang meyakinkan dan menjadi tujuan dari penelitian yang dilakukan.

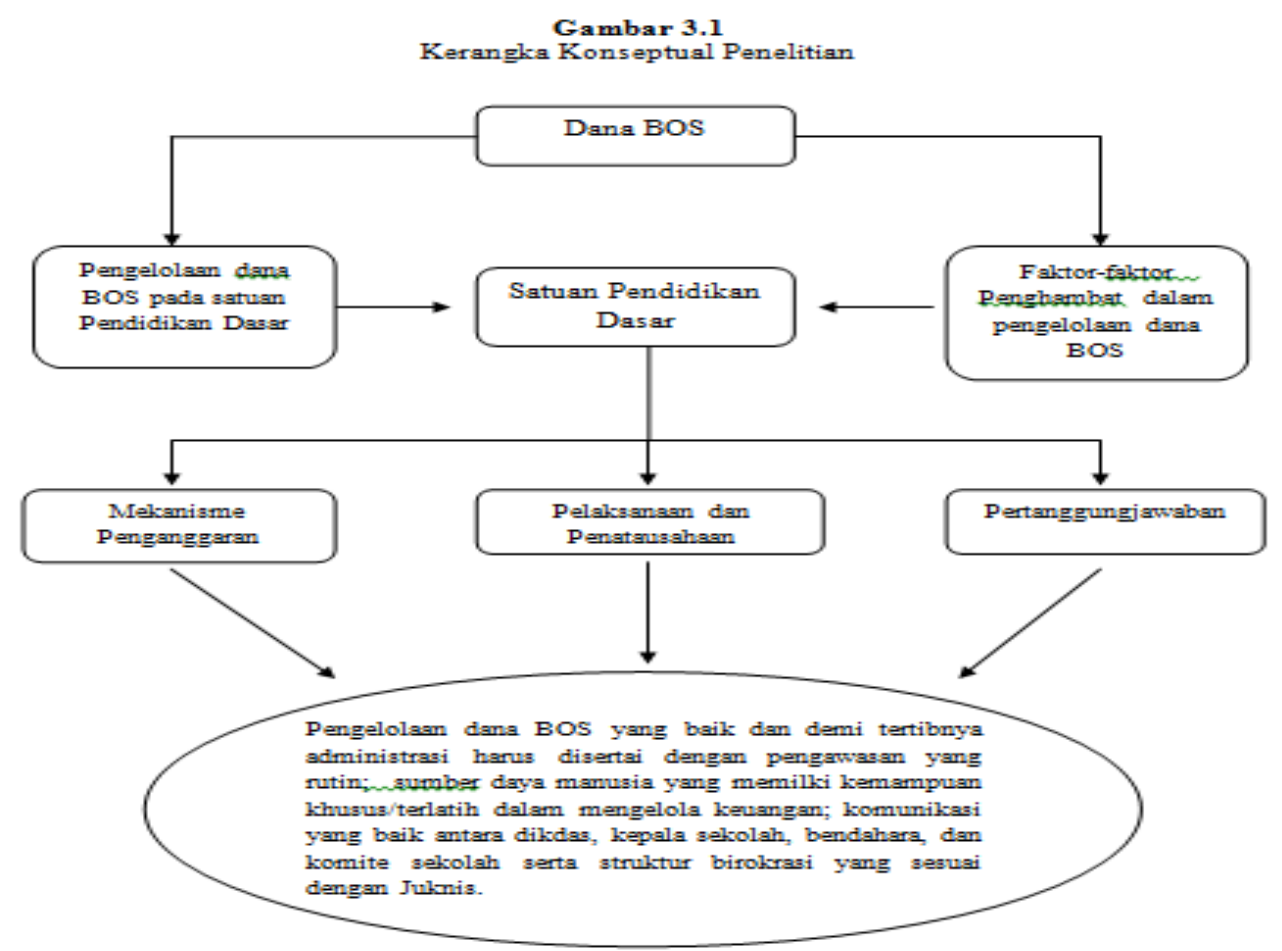

\section{MetodePenelitian}

Penelitian ini menggunakan metode penelitian kualitatif dengan pendekatan eksploratori (exploratory approach).Metode eksploratori menurut Arikunto (2010:32) adalah metode penelitian yang bertujuan untuk menggali suatu informasi. Sementara Ibrahim (2015:61) menjelaskan bahwa pendekatan ekslporatori dalam penelitian kualitatif adalah cara kerja penelitian yang dimaksudkan untuk menemukan lebih jauh dan mendalam terhadap kemungkinan-kemungkinan lain dari permasalahan yang diteliti. Dengan pendekatan eksploratori, penelitian tidak lagi sekedar mengggambarkan atau melukiskan atau menjelaskan seperti apa adanya realitas yang dikaji sebagaimana pada metode deskriptif, namun tidak melalui tahapan uji coba sebagaimana pada metode eksperimen.

Pendekatan eksploratori dalam penelitian ini berupaya menemukan informasi secara lebih lengkap atau mendetail dan mendalam, mengenai bagaimana pengelolaan dana BOS dan faktor-faktor penghambat dalam pengelolaan dana BOS pada satuan Pendidikan Dasar di Kota Kotamobagu. Dengan kata lain, penelitian ini bertujuan untuk menganalisis pengelolaan dana BOS dan faktor-faktor penghambat dalam pengelolaan dana BOS serta menggambarkan keadaan yang sebenarnya tentang pengelolaan dana BOS di sekolah dan mengungkap berbagai permasalahan yang ditemukan dalam pengelolaan dana BOS di Kota Kotamobagu. 
Satori, Djaman dan Komariah, Aan (2013:22) menjelaskan Penelitian Kualitatif adalah penelitian yang menekankan pada quality atau hal yang terpenting dari sifat suatu barang/jasa.Metode penelitian kualitatif menurut Sugiyono (2015:1) sering disebut metode penelitian naturalistik karena penelitiannya dilakukan pada kondisi yang alamiah (natural setting). Metode kualitatif ini dipilih agar data yang diperoleh akan lebih lengkap, lebih mendalam, kredibel dan bermakna sehingga tujuan penelitian dapat dicapai.

Jenis data yang digunakan dalam penelitian ini adalah data kualitatif berupa hasil wawancara mendalam dengan beberapa informan kunci pada satuan Pendidikan Dasar (SD-SMP) Kota Kotamobagu, Dinas Pendidikan Daerah Kota Kotamobagu, dan Inspektorat Kota Kotamobagu serta dokumen/arsip sekolah berupa profil sekolah dan laporan pertanggungjawaban (K-7) tahun 2016/2017, sumber data adalah orang, benda atau objek yang dapat memberikan data, informasi, fakta dan realitas yang terkait/relevan dengan apa yang dikaji atau diteliti (Ibrahim, 2015:67).

Sumber data yang digunakan dalam penelitian ini terdiri dari:

1. Data Primer adalah data dalam bentuk verbal atau kata-kata yang diucapkan secara lisan, gerak-gerik atau perilaku yang dilakukan oleh subjek yang dapat dipercaya, yakni subjek penelitan atau informan yang berkenaan dengan variabel yang diteliti atau data yang diperoleh dari responden secara langsung (Arikunto, 2010:22). Dalam penelitian ini sumber data yang didapatkan atau dikumpulkan sendiri yakni langsung diperoleh penulis dari informan atau partisipan melalui wawancara dan dokumentasi.

2. Data sekunder adalah data yang diperoleh dari teknik pengumpulan data yang menunjang data primer. Dalam penelitian ini diperoleh dari hasil observasi yang dilakukan oleh penulis serta dari studi pustaka. Dapat dikatakan data sekunder ini bisa berasal dari dokumen-dokumen grafis seperti tabel, catatan, pesan, foto dan lain-lain (Arikunto, 2010:22). Dalam penelitian ini sumber data terkait pengelolaan daan BOS yang diperoleh berupa dokumen/arsip sekolah berupa profil sekolah dan laporan pertanggungjawaban (K7) tahun 2016/2017 pada satuan Pendidikan Dasar di Kota Kotamobagu.

Menurut Sugiyono (2015:62), teknik pengumpulan data merupakan langkah yang paling strategis dalam penelitian, karena tujuan utama dalam penelitian adalah mendapatkan data. Tanpa mengetahui teknik pengumpulan data, maka tidak mungkin akan mendapatkan data yang memenuhi standar data yang ditetapkan. Sedangkan menurut Ibrahim (2015:80), bahwa dalam penelitian kualitatif teknik pengumpulan data secara umum yang lazim digunakan adalah observasi/pengamatan, wawancara, studi dokumentasi untuk menghimpun data (teks) atau gambar (foto), dan focus group discussion. Namun,teknik pengumpulan data yang ditempuh dalam penelitian ini adalah melalui wawancara mendalam (in-depth interviews) dan dokumentasi (documentation).

Analisis data dimulai dengan menggunakan content analysis yaitu membuat transkrip hasil wawancara, dengan cara memutar kembali rekaman hasil wawancara, mendengarkan dengan saksama, kemudian menuliskan kata-kata yang didengar sesuai dengan apa yang ada di rekaman tersebut. Langkah selanjutnya dari analisis data kualitatif yang digunakan dalam penelitian ini adalah teknik analisis isi menurut Model Miles dan Huberman. Aktivitas analisis data Miles and Huberman (1984) dalam Sugiyono (2015:91) terdiri atas: data reduction, data display dan conclusion drawing/verification yang dilakukan secara interaktif dan berlangsung secara terus menerus sampai tuntas, sehingga datanya mencapai jenuh.

\section{Analisis dan Pembahasan}

Penelitian ini dilakukan selama kurang lebih tiga (3) bulan dari bulan Juli 2017 sampai bulan September 2017. Dalam melakukan penelitian, menggunakan instrumen-instrumen pendukung diantaranya: buku catatan (notebook), pedoman wawancara, alat perekam berupa audio/tab untuk merekam pelaksanaan wawancara dengan informan yang hasilnya ditranskrip menjadi transkrip data, kamera handphone untuk mendokumentasikan kegiatan penelitian dilapangan, dan laptop sebagai penunjang dalam penelitian. Selain itu, pengalaman penulis sebelum melanjutkan studi adalah bendahara rutin/pengeluaran di Badan Penanggulangan Bencana Daerah Kota Kotamobagu selama 3 (tiga) tahun menjadi referensi dan informasi dalam memecahkan permasalahan dalam penelitian ini.

\section{Pengelolaan dana Bantuan Operasional Sekolah (BOS) berdasarkan Permendagri Nomor 62 Tahun 2011 1. Mekanisme Penganggaran,}

Juknis dana BOS di atur dalam Permendikbud Nomor 08 tahun 2017 tentang petunjuk teknis penggunaan dana BOS tahun 2017 yaitu ada 11 item/komponen dan 8 standar belanja yang dapat digunakan dalam pengelolaan dana BOS (Juknis lama 13 item/komponen belanja). Hal ini menurut Septiani (2005), bahwa seseorang individu cenderung mematuhi hukum yang mereka anggap sesuai dan konsisten dengan normanorma internal mereka.Komitmen normatif melalui moralitas personal (normative commitment through morality) berarti mematuhi hukum karena hukum tersebut dianggap sebagai keharusan, sedangkan komitmen 
normatif melalui legitimasi (normative commitment through legitimacy) berarti mematuhi peraturan karena otoritas penyusun hukum tersebut memiliki hak untuk mendikte perilaku.Artinya, setiap kegiatan yang dilakukan dalam penganggaran harus sesuai dengan Juknis atau aturan yang ada.

Menurut Welsch, Glenn A., Hilton, Ronald W dan Gordon, Paul N (2000:5), anggaran adalah perencanaan untuk pengendalian laba menyeluruh dapat didefenisikan secara luas sebagai suatu anggaran sistematis dan formal untuk perencanaan, pengkoordinasian dan pengendalian tanggung jawab manajemen. Dalam hal ini, dana BOS yang diterima harus dipergunakan sesuai dengan Juknis yang ada. Kalau untuk keterlambatan ya mungkin, pihak sekolah juga sudah mengantisipasi yaitu dengan memanfaatkan buku yang tahun sebelumnya karena untuk kurikulum 2013 ini, tahun sebelumnya yang dipesan oleh pihak sekolah yaitu pada semester pertama kurang lebih pendanaannya itu juga $20 \%$ tapi belum terealisasi secara keseluruhan.

Penggunaan dana BOS yang diperuntukkan untuk pengadaan buku (K-13) bagi siswa hanya bisa digunakan pada triwulan II sebanyak $20 \%$ dari anggaran yang ada. Namun dalam pelaksanaannya pihak sekolah khususnya di SMP Negeri 1 tidak merealisasikannya dalam triwulan tersebut pada hal dananya sudah ada, tapi dialokasikan ke kegiatan lain karena penyedia buku yang datang terlambat sehingga dana yang seharusnya diperuntukkan untuk pengadaan buku (K-13) di triwulan II nanti direalisasikan di triwulan III, dikaitkan dengan teori anggaran menurut Silalahi (2015:174) yang adalah suatu ramalan yang rinci tentang hasil yang diharapkan dan biaya yang dikeluarkan dari suatu program operasi yang diakui secara resmi didasarkan pada harapan yang tinggi tentang efisiensi pelaksanaan. Anggaran dapat dianggap sebagai alat pengendali aktivitas organisasi dan elemen penting dalam implementasi program atau proyek karena dalam anggaran ditetapkan secara rinci pendapatan dan pengeluaran organisasi seperti anggaran pendapatan dan belanja Negara. Artinya, dalam pengelolaan dana BOS semua rincian biaya yang dikeluarkan harus sesuai dengan aturan yang ada dalam penggunaan dana BOS yaitu untuk 11 komponen belanja (Juknis lama 13 komponen belanja) sehingga dalam pelaksanaannya semua belanja-belanja itu dapat terkendali karena ada aturan yang mengaturnya.

\section{Pelaksanaan Dan Penatausahaan}

Penyaluran dana BOS dari RKUD Provinsi ke rekening dana BOS masing-masing satuan pendidikan negeri, dilakukan setelah penandatanganan NPH BOS. Penerimaan dana BOS pada masing-masing Satuan Pendidikan, diakui sebagai pendapatan SKPD Dinas Pendidikan pada Kabupaten/Kota untuk digunakan langsung dalam rangka pelayanan pendidikan pada masing-masing satuan pendidikan negeri. Dalam pelaksanaan dan penatausahaan termasuk didalamnya penyaluran dan penggunaan dana BOS.

Pelaksanaan dana BOS dimulai dari pelaporan dulu setelah laporan sudah masuk secara keseluruhan dari semua sekolah yang ada kemudian diproses lagi dan diajukan ke propinsi dari propinsi mengajukan ke manajemen BOS di pusat khususnya di satuan pendidikan dasar pusat dari pusat kemudian mereka transfer ke kas propinsi, dari propinsi baru masuk ke rekening masing-masing sekolah. Sedangkan untuk proses penyalurannya itu, ada jumlah-jumlah yang harus disalurkan ke misalnya dalam standar pendidikan dan tenaga kependidikan contohnya untuk pembiayaan siswa baru atau pembiayaan guru honor, dan lain-lain. Jadi jumlahnya itu sudah dianggarkan dalam RKAS (Rencana Kegiatan dan Anggaran Sekolah).

Teori Stewardship menyatakan bahwa pengelolaan ini menggambarkan situasi dimana manajemen tidaklah termotivasi oleh tujuan-tujuan individu tetapi lebih ditujukan pada sasaran hasil utama mereka untuk kepentingan organisasi.Teori tersebut mengasumsikan adanya hubungan yang kuat antara kepuasan dan kesuksesan organisasi. Kesuksesan organisasi menggambarkan maksimalisasi utilitas kelompok principals dan manajemen. Maksimalisasi utilitas kelompok inipada akhirnya akanmemaksimumkan kepentingan individu yang ada dalam kelompok organisasi tersebut.

Sedangkan dalam penggunaan dana BOS, menurut Mill dikutip oleh Lebacqz (1986) menyimpulkan bahwa tidak ada teori keadilan yang bisa dipisahkan dari tuntutan kemanfaatan. Keadilan adalah istilah yang diberikan kepada aturan-aturan yang melindungi klaim-klaim yang dianggap esensial bagi kesejahteraan masyarakat.Klaim-klaim untuk memegang janji, diperlakukan dengan setara dan sebagainya.Sifat-sifat esensial keadilan didalam skema utilitarian yaitu, keadilan mengakui eksistensi hak-hak individu yang didukung masyarakat.Keadilan bagi Mill mensyaratkan aturan-aturan yang ditetapkan menjadi kebaikan masyarakat demi menjamin pemenuhan kewajiban-kewajiban tertentu yang keras dan demi melindungi hak-hak individu.

\section{Pertanggungjawaban}

Berdasarkan SP2B satuan pendidikan, Kepala SKPD Dinas Pendidikan menyusun laporan realisasi pendapatan dan belanja yang bersumber dari dana BOS serta menyajikan dalam laporan keuangan SKPD Dinas 
Pendidikan pada Kabupaten/Kota yang akan dikonsolidasikan menjadi Laporan Keuangan Pemerintah Daerah (LKPD) sesuai dengan ketentuan Peraturan Perundang-Undangan di bidang pengelolaan keuangan daerah.

Dalam pertanggungjawaban, menurut Sujarweni (2015:1) bahwa akuntansi merupakan suatu aktivitas jasa yang terdiri dari mencatat, mengklasifikasikan, dan melaporkan kejadian atau transaksi ekonomi yang akhirnya akan menghasilkan suatu informasi keuangan yang akan dibutuhkan oleh pihak-pihak tertentu untuk pengambilan keputusan. Sedangkan pengertian akuntansi keuangan menurut Kieso dan Weygandt (2016:6) adalah suatu rangkaian proses yang berujung pada penyusunan laporan keuangan yang berkaitan dengan perusahaan secara keseluruhan untuk digunakan oleh pengguna laporan keuangan baik di dalam ataupun di luar perusahaan.Untuk dapat menghasilkan laporan keuangan yang relevan, handal dan dapat dipercaya, pemerintah Daerah harus memiliki sistem akuntansi yang handal.Sistem akuntansi yang lemah menyebabkan pengendalian intern lemah dan pada ahkirnya laporan keuangan yang dihasilkan kurang handal dan kurang relevan untuk pembuatan keputusan (Mardiasmo, 2002:34).

Tata kelola pemerintahan yang baik merupakah salah satu tuntutan masyarakat yang harus dipenuhi.Salah satu pilar tata kelola tersebut adalah akuntabilitas.Akuntabilitas adalah mempertanggungjawabkan pengelolaan sumber daya serta pelaksanaan kebijakan yang dipercayakan kepada entitas pelaporan dalam mencapai tujuan yang telah ditetapkan secara periodic (SAP,2005). Sabeni dan Ghozali (2001) dalam Sujarweni (2015) menyatakan "Akuntabilitas atau pertanggungjawaban (accounttability) merupakan suatu bentuk keharusan seseorang (pimpinan/pejabat/pelaksana) untuk menjamin bahwa tugas dan kewajiban yang diembannya sudah dilaksanakan sesuai dengan ketentuan yang berlaku.Akuntabilitas dapat dilihat melalui laporan tertulis yang informatif dan transparan".

Mardiasmo (2002) dalam Sujarweni (2015) menjelaskan "Akuntabilitas Publik adalah kewajiban pihak pemegang amanah untuk memberikan pertanggungjawaban, menyajikan dan mengungkapkan segala aktivitasnya dan kegiatan yang menjadi tanggungjawabnya kepada pihak pemberi amanah (principal) yang memiliki hak dan kewenangan untuk meminta pertanggungjawaban tersebut”.

\section{Hambatan-hambatan dalam pengelolaan dana Bantuan Operasional Sekolah (BOS)}

\section{Hambatan Pengawasan}

Dalam hambatan pengawasan ditemukan bahwa tidak adanya komite sekolah selaku pengontrol/pengawasan dalam pengelolaan dana BOS disekolah dan pengawasan dari Inspektorat Daerah Kota Kotamobagu yang tidak dilakukan secara rutin, pengawasan dalam hal audit dana BOS.

Suharsimi Arikunto (1988) mengatakan bahwa pengelolaan adalah substantif dari mengelola sedangkan mengelola berarti suatu tindakan yang dimulai dari penyusunan data, merencana, mengorganisasikan, melaksanakan, sampai dengan pengawasan dan penilaian.Artinya, segala bentuk kebijakan/bantuan dari Pemerintah yang dikelola harus sesuai dengan aturan yang berlaku. Dalam hal ini, komite sekolah yang berfungsi sebagai pengontrol/pengawasan dalam pengelolaan dana BOS tidak diaktifkan

Pengawasan sangat diperlukan dalam pengelolaan dana BOS, sesuai dengan Peraturan Menteri Pendidikan Dan Kebudayaan Nomor 16 Tahun 2016 tentang Perubahan atas Peraturan Menteri Pendidikan Dan Kebudayaan Nomor 80 Tahun 2015 tentang petunjuk teknis penggunaan dan pertanggungjawaban keuangan dana BOS. Dimana pada BabVIII menjelaskan mengenai pengawasan, pemeriksaan dan sanksi.

Pengawasan pada program BOS meliputi: (1) Pengawasan yang melekat yaitu pengawasan yang dilakukan oleh pimpinan SKPD Pendidikan Kabupaten/Kota kepada sekolah; (2) Pengawasan fungsional Internal yaitu pengawasan oleh Inspektorat Jenderal Kemendikbud serta Inspektorat Daerah Propinsi dan Kabupaten/Kota dengan melakukan audit sesuai kebutuhan lembaga tersebut atau permintaan instansi yang akan di audit, serta sesuai dengan wilayah kewenangan masing-masing; (3) Pengawasan oleh BPKP yaitu dengan melakukan audit atas permintaan instansi yang akan di audit; (4) Pemeriksaan oleh BPK yaitu sesuai dengan kewenangan; dan (5) Pengawasan masyarakat, dalam rangka transparansi pelaksanaan program BOS oleh unsur masyarakat dan unit-unit pengaduan masyarakat yang terdapat di sekolah, Kabupaten/Kota, Propinsi, dan Pusat mengacu pada kaedah keterbukaan informasi publik, yaitu semua dokumen BOS dapat di akses oleh publik kecuali yang dirahasiakan.

\section{Hambatan Sumber Daya}

Kontrak hubungan antara Stewards dan principals atas dasar kepercayaan (amanah=trust), bertindak kolektif sesuai dengan tujuan organisasi, sehingga model yang sesuai pada kasus organisasi sektor publik adalah Stewardship theory. Teori ini merupakan penatalayanan dimana kaitannya terhadap organisasi didalamkepemerintahan. Hal ini menjadi hambatan sumber daya dalam pengelolaan dana BOS, dimana bendahara tidak memegang uang karena uang dipegang oleh kepala sekolah. 
Dalam pengelolaan dana BOS, hal ini sangat bertentangan dengan aturan/Juknis dilihat dari tupoksinya karena tugas pokok bendahara selaku pengelola dana BOS tidak berfungsi dengan baik. Yusuf (2015) mendefinisikan sumber daya sebagai alat untuk mencapai tujuan atau kemampuan memperoleh keuntungan dari kesempatan-kesempatan yang ada.Perkataan sumber daya (resources) merefleksikan apprasial manusia.Sumber daya merupakan suatu abstraksi yang mencerminkan apprasial manusia dan berhubungan dengan suatu fungsi atau operasi.Sumber daya manusia meliputi seluruh individu yang terlibat dalam organisasi dan masing-masing memiliki peran dan fungsi tersendiri dalam pencapaian tujuan organisasi.

Dalam upaya mengatasi hambatan sumber daya disini mungkin lebih ke sumber daya manusianya lebih dahulu.Silalahi (2015: 242) menyatakan SDM merupakan elemen penting dan merupakan aset terpenting dari organisasi dibanding dengan elemen lainnya.Manusia dalam organisasi memiliki peran dan fungsi penting bagi terwujudnya tujuan organisasi.Manusia yang membuat sumber-sumber lain dari suatu organisasi bekerja dan membuat organisasi bergerak.

\section{Hambatan Komunikasi}

Komunikasi merupakan proses yang menghubungkan berbagai komponen-komponen dari berbagai organisasi secara bersama baik secara vertikal maupun horizontal dan diagonal. Komunikasi berlangsung didalam dan di antara unit-unit organisasi sehingga organisasi menjadi dinamis.dan dalam organisasi, komunikasi mempengaruhi setiap individual yang bekerja untuk organisasi (Silalahi, 2015:270). Hambatan komunikasi dalam hal ini adalah pengadaan buku (K-13) yang dianggarkan tidak sesuai aturan dan komunikasi antara ombudsman yang melarang orangtua memberikan sumbangan kepada pihak sekolah dalam pengelolaan dana BOS.

Berdasarkan hasil penelitian komunikasi antara pihak sekolah dan orang tua murid serta ombudsman tidak begitu baik dikarenakan program yang ada di sekolah bertentangan dengan ombudsman. Silalahi(2015:274275) menyatakan komunikasi penting karena fungsinya dalam organisasi. Pegawai menetapkan tujuan-tujuan spesifik, bekerja untuk memenuhi tujuan tersebut dan menerima balikan tetang progres terhadap tujuan-tujuan itu.Untuk komunikasi diperlukan karena dapat berfungsi sebagai :

a) Fungsi kontrol. Melalui komunikasi dapat dikontrol perilaku atau kegiatan anggota kelompok dengan cara tertentu;

b) Fungsi motivasi. Melalui komunikasi dapat ditingkatkan komunikasi pegawai dengan menjelaskaapa yang harus dikerjakan, seberapa baik yang mereka kerjakan dan apa yag dapat dikerjakan untuk meningkatkan kinerja mereka.

c) Fungsi ekspresi emosi. Melalui komunikasi tiap anggota dapat mengungkapkan perasaan mereka, seperti rasa puas atau tidak puas dan pemenuhan sosial kebutuhan mereka;

d) Fungsi informasi. Komunikasi menyampaikan informasi dari pimpinan ke bawahan atau sebaliknya.Fungsi ini juga memberi petunjuk, pedoman atau informasi yang diperlukan oleh pimpinan atau bawahan.Komunikasi berfungsi menyampaikan informasi yang berhubungan dengan kepentigan umum dan lingkungan tugas organisasi secara keseluruhan. Komunikasi berfungsi menyampaikan informasi dan pengetahuan terutama yang berhubungan dengan pekerjaan atau pelaksanaan tugas dari seseorang kepada orang lain sehingga pekerjaan dapat dijalankan secara benar dan kerjasama tercipta;

e) Fungsi komando. Melalui komunikasi atasan memberi instruksi pelaksanaan tugas-tugas tentang apa yang harus dikerjaka kepada bawahan. Komunikasi mendorong dan mengarahkan pegawai untuk melakukan pekerjaan;

f) Fungsi integratif. Melalui komunikasi dapat diintegrasikanpekerjaaan dan unit-unit sehingga antara karyawan dan manajer menunjukkan kepaduan (cohesiveness).Disamping itu komunikasi membantu memelihara hubungan sosial orgaisasional dan membangun kebersamaan orang-orang yang melakukan kerjasama.

Jika dikaitkan dengan teori Edward III dalam Tahir (2014) dapat disimpulkan bahwa implementasikan kebijakan dapat berjalan secara efektif, apabila yang harus bertanggungjawab terhadap implementasi sebuah kebijakan mengetahui apa yang dilakukannya dan perintah untuk mengimplementasikan kebijakan harus disampaikan secara jelas, akurat dan konsisten kepada orang-orang yang mampu.

\section{Hambatan Struktur Birokrasi}

Hambatan dalam struktur birokrasi adalah keterlambatan pencairan dana BOS atau pencairan yang tidak tepat waktu mengakibatkan kegiatan yang sudah terprogram tidak terealisasi dengan baik dan penggunaan dana BOS yang tidak sesuai dengan Juknis, misalnya pengadaan printer. Printer itu dibatasi 1 unit dalam 1 tahun, kalau diambil 2 tidak boleh. 
Pencairan dana BOS yang tidak tepat waktu yang mengakibatkan keterlambatan dalam proses operasional sekolah dan pengadaan printer yang hanya diperbolehkan 1 unit dalam 1 tahun, maka hal ini bertentangan dengan Juknis yang ada dan otomatis menjadi hambatan dalam proses pengelolaan dana BOS.

Dikaitkan dengan Teori Edward III dalam Tahir (2014) dapat disimpulkan bahwa meskipun sumber daya untuk mengimplementasikan kebijakan telah mencukupi dan para pelaksana mengetahui apa yang harus dilakukan serta bersedia melaksanakannya, implementasi kebijakan masih terhambat oleh permasalahan struktur birokrasi. Struktur organisasi yang lemah dapat menghambat koordinasi yang diperlukan guna keberhasilan implementasi sebuah kebijakan yang membutuhkan kerja sama dengan banyak orang. Hal ini menyebabkan terbuangnya sumber daya yang pendukung lainnya, menutup kesempatan, menciptakan kebingungan, menggiring kebijakan bukan kepada tujuan dan mengakibatkan fungsi-fungsi yang penting lainnya menjadi terlupakan.

Dalam kamus besar Bahasa Indonesia, struktur birokrasi adalah sebuah struktur dengan tugas-tugas operasi yang sangat rutin yang dicapai melalui spesialisasi, aturan dan ketentuan yang sangat formal, tugas-tugas yang dikelompokkan ke dalam berbagai departemen fungsional, wewenang terpusat, rentang kendali yang sempit, dan pengambilan keputusan yang mengikuti rantai komando.

\section{Penutup}

Kesimpulan Penelitian ini adalah:

1. Pengelolaan dana BOS yang berdasarkan Peraturan Menteri Dalam Negeri Nomor 62 tahun 2011 terdiri atas:

a. Mekanisme penganggaran dalam pengelolaan dana BOS harus sesuai dengan juknis yang ada.

b. Pelaksanaan dan penatausahaan dalam pengelolaan dana BOS melalui penyaluran dan penggunaan dana BOS, sering terlambat dalam penyaluran dana BOS sehingga mengakibatkan pihak sekolah harus pinjam uang ketempat lain untuk merealisasikan kegiatan yang sudah terprogram di triwulan tersebut.

c. Pertanggungjawaban dalam pengelolaan dana BOS dalam bentuk LPJ atau K-7a dan harus ditandatangani oleh kepala sekolah, bendahara dan komite sekolah tiap triwulan dan dilaporkan langsung ke Dinas Pendidikan Daerah Kota Kotamobagu.

2. Hambatan-hambatan dalam pengelolaan dana BOS yaitu:

a. Pengawasan, tidak ada pengawasan di SD Negeri 1 Kotamobagu dan SD Negeri 3 Gogagoman dari komite sekolah karena sekolah-sekolah tersebut tidak mengaktifkan komite sekolahnya (komite sekolah vakum). BPK, BPKP dan Inspektorat Propinsi/Daerah juga belum melakukan audit terhadap pengelolaan dana BOS di Kota Kotamobagu.

b. Sumber daya manusia, peningkatan kemampuan atau keterampilan SDM melalui kegiatan bimbingan teknis (Bimtek) yang teratur dan rutin dilaksanakan.

c. Komunikasi aktif dan sosialisasi harus dilakukan oleh semua pihak yang terkait dalam pengelolaan dana BOS.

d. Struktur birokrasi, keterlambatan pencairan dana BOS atau pencairan yang tidak tepat waktu.

Saran yang dapat diberikan dari penelitian ini:

1. Perlu adanya pengawasan yang rutin setiap tahun baik dari BPK, BPKP, maupun Inspektorat Daerah Kota Kotamobagu dalam pengelolaan dana BOS di sekolah-sekolah.

2. Untuk lebih memberdayakan sumber daya manusia yang sesuai dengan tupoksi yang ada dalam pengelolaan dana BOS.

3. Perlu segera membentuk kembali komite-komite sekolah yang sudah vakum, agar tercipta komunikasi yang lebih baik antara sekolah, siswa, dan orang tua.

4. Lebih memahami struktur birokrasi yang ada dan dapat melaksanakannya tepat waktu sehingga semua yang direncanakan dapat terealisasi sesuai dengan peruntukkannya dalam pengelolaan dana BOS.

5. Untuk penelitian selanjutnya, supaya lebih menggali topik atau tema-tema yang lain sehubungan dengan pengelolaan dana BOS selain faktor-faktor penghambat dalam pengelolaan dana BOS.

\section{Daftar Pustaka}

Arikunto, Suharsimi. 1988. Prosedur Penelitian: Pengelolaan Kelas dan Siswa. Jakarta: CV. Rajawali. 2010. Prosedur Penelitian: Suatu Pendekatan Praktik. Jakarta: Rineka Cipta.

Ibrahim. 2015. Metodologi Penelitian Kualitatif: Panduan Penelitian Beserta Contoh Proposal Kualitatif. Bandung :Alfabeta. 
Burhanuddin, Yusuf. 2015. "Manajemen Sumber Daya Manusia di Lembaga Keuangan Syariah”. Jakarta: PT. Raja Grafindo Persada.

Deliknews. 2016. Situs berita online: https://www.deliknews.com/.../soal-dana-bos-rukmini-saya-tegaskanuntuk-tepat-sasaran.

Kamus Besar Bahasa Indonesia (KBBI) online https://kbbi.web.id/.

Kementerian Keuangan-Direktorat Jenderal Perimbangan Keuangan, 2017 tentang sosialisasi Bantuan Operasional Sekolah kepada Tim Manajer Bantuan Operasional Sekolah Propinsi dan Kabupaten/Kota.

Kieso, Donald E dan Weygandt, Jerry J. 2016. Intermediate Accounting: Akuntansi Intermediate. Diterjemahkan Herman Wibowo, Edisi ketujuh.Jilid 1. Jakarta: Binarupa Aksara.

Lebacqz, Karen. 1986. “Teori-teori Keadilan”, Penerjemah YudiSantoso, Bandung: Nusa Media.

Mardiasmo. 2002. "Akuntansi Sektor Publik”, Yogyakarta: CV. Andi.

Peraturan Menteri Dalam Negeri Republik Indonesia Nomor 62 Tahun 2011Tentang Pedoman Pengelolaan Bantuan Operasional Sekolah.

Nomor 13 Tahun 2006 tentang Pedoman Pengelolaan Keuangan Daerah, sebagaimana telah diubah dengan Peraturan Menteri Dalam Negeri Nomor 59 Tahun 2007, dan diubah terakhir dengan Peraturan Menteri Dalam Negeri Nomor 21 Tahun 2011.

Peraturan Menteri Pendidikan dan Kebudayaan Nomor 51 Tahun 2011 tentang Petunjuk Teknis Pengelolaan Dana Bantuan Operasional Sekolah.

Nomor 16 Tahun 2016 tentang perubahan atas Peraturan Menteri Pendidikan dan Kebudayaan Nomor 80 tahun 2015 tentang Petunjuk Teknis Penggunaan dan Pertanggungjawaban Keuangan Dana Bantuan Operasional Sekolah.

PMK No 201 tentang Pedoman Umum dan Alokasi Bantuan Operasional Sekolah Tahun 2012.

Peraturan Pemerintah Nomor 24 Tahun 2005 Tentang Standar Akuntansi Pemerintahan.

. Nomor 43 Tahun 2015 Tentang Peraturan Pelaksana Undang-undang Nomor 6 Tahun 2015

Satori, Djaman dan Komariah, Aan. 2013. "Metodologi Penelitian Kualitatif". Bandung: CV. Alfabeta.

Septiani, Aditya. 2005. "Faktor-Faktor Yang Mempengaruhi Ketepatwaktuan Pelaporan Keuangan Pada Pasar Modal Yang Sedang Berkembang”;Perpektif Teori Pengungkapan.

Silalahi, Ulber. 2015. “Asas-Asas Manajemen”. Bandung: PT. Refika Aditama.

Sugiyono. 2015. "Memahami Penelitian Kualitatif". Dilengkapi contoh proposal dan laporan Penelitian, Bandung: CV Alfabeta.

Suharmisi., Sugiyono.2015, “Metode Penelitian Manajemen”.Bandung: CV. Alfabeta.

Sujarweni V. Wiratna. 2015. “Akuntansi Sektor Publik”. Yogyakarta: Pustaka Baru Press.

Tahir Arifin. 2014. "Kebijakan Publik \& Transparansi Penyelenggaraan Pemerintah Daerah". Bandung: CV. Alfabeta.

Undang-Undang Nomor 32 Tahun 2004 Tentang Pemerintahan Daerah. 2009. Jakarta: Departemen Keuangan Republik Indonesia.

Welsch, Glenn A., Hilton, Ronald W dan Gordon, Paul N. 2000. Anggaran Perencanaan dan Pengendalian Laba.Diterjemahkan oleh Purwatiningsih dan MaudyWarouw. Buku Satu. Salemba Empat. Jakarta. 